\title{
Pelaksanaan Pendidikan Karakter dalam Pembelajaran Akhlak Mahasiswa PGMI
}

\author{
Nur Hasanah \\ Sekolah Tinggi Agama Islam Negeri (STAIN) Salatiga \\ Email: nurhasanah201157@yahoo.com
}

\begin{abstract}
Abstrak
Penelitian ini bertujuan untuk mengetahui pendidikan karakter mahasiswa jurusan Pendidikan Guru Madrasah Ibtidaiyah (PGMI), pelaksanaannya, juga faktor-faktor penghambat dan pendukung pelaksanaan pendidikan karakter pembelajaran akhlak dari mahasiswa PGMI. Penelitian ini memfokuskan pada pelaksanaan pendidikan karakter mahasiswa PGMI. Subyek penelitian ini adalah dosen mata kuliah akhlak dan mahasiswa jurusan PGMI semester empat STAIN Salatiga. Data dikumpulkan dengan cara observasi, wawancara, dan dokumentasi. Temuan penelitian menunjukkan bahwa pendidikan karakter mahassiswa PGMI dalam kondisi baik. Hanya rasa ingin tahu dan indikator peduli lingkungan yang masih kurang. Strategi implementasi dalam penelitian ini adalah dengan contoh atau keteladanan, perumpamaan, pembiasaan dan saran atau peringatan. Sedangkan faktor penghambat dan pendukung yang berasal dari faktor internal individu siswa dan keluarga serta faktor-faktor lain yang berkontribusi. Sedangkan faktor eksternal adalah metode pembelajaran dan media serta faktor lingkungan kampus dan komunitas. Kampus dan faktor lingkungan masyarakat menjadi kendala untuk melaksanakan pendidikan karakter mahasiswa jurusan Pendidikan Guru Madrasah Ibtidaiyah (PGMI).
\end{abstract}

The study is aimed to determine the students' character education of Islamic Primary Teacher Education (PGMI) department, the 
implementation also the factors inhibiting and supporting the implementation of character education in the learning morals (akhlak) of PGMI students. This study focuses on the implementation of students' character education in Islamic Primary Teacher Education (PGMI) department. The subjects of this research are the lecturers of moral (akhlak) subject and the fourths semester students of Islamic Primary Teacher Education (PGMI) department STAIN Salatiga. The data is collected by observation, interviews, and documentation. Research findings show that character education of Islamic Primary Teacher Education (PGMI) department students have been in a good condition. The only curiosity and care to environment indicators that still less. The implementation strategy in this research is by example, parable, habituation and advice or warning. While the inhibiting and supporting factors are derived from the internal factors of individual students and families as well as the contributing factors. While the external factors are instructional methods and media as well as campus and community environmental factors. Campus and community environmental factors become the obstacle to implement the character education of Islamic Primary Teacher Education (PGMI) department students.

Kata kunci: karakter, akhlak, Pendidikan Guru Madrasah Ibtidaiyah

\section{Pendahuluan}

Undang-Undang Sisdiknas Nomor 20 Tahun 2003 menyatakan bahwa tujuan pendidikan nasional adalah berkembangnya potensi peserta didik agar menjadi manusia yang beriman dan bertakwa kepada Tuhan Yang Maha Esa, berakhlak mulia, sehat, berilmu, cakap, kreatif, mandiri, dan menjadi warga negara yang demokratis serta bertanggung jawab. Upaya mewujudkan tujuan pendidikan nasional tersebut maka pemerintah melakukan terobosan dengan menekankan pelaksanaan pendidkan karakter yang ditempuh melalui jalur pendidikan formal 
maupun non formal, yang dimulai dari jenjang sekolah dasar sampai perguruan tinggi baik perguruan tinggi umum maupun Islam.

Menurut Muslih (2011: 69) pendidikan adalah proses internalisasi budaya dalam diri seseorang dan masyarakat sehingga membuat orang dan masyarakat jadi beradab. Pendidikan dalam konteks ini bukan transfer of knowledge, tapi lebih luas lagi yaitu sebagai sarana pembudayaan dan penyaluran nilai.

Sedangkan pendidikan karakter Menurut Muslih (2007: 45) Secara operasional adalah upaya untuk membekali mahasiswa melalui kegiatan bimbingan, pengajaran, dan latihan selama perkembangan dirinya sebagai bekal masa depannya, agar memiliki hati nurani yang bersih, berperangai baik, serta menjaga kesusilaan dalam melaksanakan kewajiban terhadap Tuhan dan terhadap sesama makhluknyasehingga terbentuk pribadi seutuhnya yang tercermin pada perilaku berupa ucapan, perbuatan,sikap, pikiran, perasaanserta norma dan moral luhur bangsa. Agar nilai-nilai karakter tersebut dapat terintegrasi dan dilaksanakan dalam kehidupan sehari-hari baik di rumah, di sekolah, maupun di masyarakat maka diperlukan strategi pelaksanaan.

Karakter menurut Pusat Bahasa Depdiknas adalah "bawaan, hati, jiwa, kepribadian, budi pekerti, perilaku, personalitas, sifat, tabiat, temperamen, watak". Adapun berkarakter adalah berkepribadian, berperilaku, bersifat, bertabiat, dan berwatak". Namun jika istilah karakter dihubungkan dan dipertukarkan dengan istilah etika, akhlak, dan atau nilai dan berkaitan dengan kekuatan moral, berkonotasi positif bukan netral. Dengan demikian karakter adalah nilai-nilai yang unik-baik 
yang terpateri dalam diri dan terejawantahkan dalam perilaku. Karakter secara koheren memancar dari hasil olah pikir, olah hati, olah rasa dan karsa, serta olahraga seseorang atau sekelompok orang.

Menurut Tadkiroatun Musfiroh dalam Miftachurrif'ah (2012: 8), karakter mengacu kepada serangkaian sikap (attitudes), perilaku (behaviors), motivasi (motivations), dan keterampilan (skills). Karakter berasal dari bahasa Yunani yang berarti "to mark" atau menandai dan memfokuskan bagaimana mengaplikasikan nilai kebaikan dalam bentuk tindakan atau tingkah laku, sehingga orang yang tidak jujur, kejam, rakus dan perilaku jelek lainnya dikatakan orang berkarakter jelek. Sebaliknya, orang yang perilakunya sesuai dengan kaidah moral disebut dengan berkarakter mulia.

Sedangkan Samsuri (2011: 31) menjelaskan bahwa terminologi "karakter" itu sendiri sedikitnya memuat dua hal: values (nilai-nilai) dan kepribadian. Suatu karakter merupakan cerminan dari nilai apa yang melekat dalam sebuah entitas. "Karakter yang baik" pada gilirannya adalah suatu penampakan dari nilai yang baik pula yang dimiliki oleh orang atau sesuatu, di luar persoalan apakah "baik" sebagai sesuatu yang "asli" ataukah sekadar kamuflase. Dari hal ini, maka kajian pendidikan karakter akan bersentuhan dengan wilayah filsafat moral atau etika yang bersifat universal, seperti kejujuran.

Lebih lanjut dikatakan bahwa ada beberapa penamaan yang merujuk kepada kajian pembentukan karakter peserta didik, tergantung kepada aspek penekanannya. Di antaranya yang umum dikenal ialah: Pendidikan Moral, Pendidikan Nilai, Pendidikan Relijius, Pendidikan 
Budi Pekerti, dan Pendidikan Karakter itu sendiri. Masing-masing penamaan kadang-kadang digunakan secara saling bertukaran (interexchanging), misal pendidikan karakter juga merupakan pendidikan nilai atau pendidikan relijius itu sendiri.

Dalam Grand Desain Pendidikan Karakter, disebutkan bahwa pendidikan karakter adalah proses pemberian tuntunan peserta/anak didik agar menjadi manusia seutuhnya yang berkarakter dalam dimensi hati, pikir, raga, serta rasa dan karsa. Peserta didik diharapkan memiliki karakter yang baik meliputi kejujuran, tanggung jawab, cerdas, bersih dan sehat, peduli, dan kreatif. Karakter tersebut diharapkan menjadi kepribadian utuh yang mencerminkan keselarasan dan keharmonisan dari olah hati, pikir, raga, serta rasa dan karsa. (http://pendikar.unnes.ac.id/)

Perguruan tinggi Islam khususnya merupakan lembaga pendidikan yang mencetak generasi yang berkualitas yang diharapkan dapat memiliki kecerdasan intelektual, emosional, dan spiritual serta karakter yang baik. Hal ini sebagaimana STAIN Salatiga dengan misinya mencetak mahasiswa yang beriman, bertakwa, berbudi pekerti yang luhur dan berakhlakul karimah memiliki karakter yang baik, terutama mahasiswa PGMI (Pendidikan Guru Madrasah ibtidaiyah) yang mencetak calon guru MI yang berkarakter baik dan benar.

Di PGMI pendidikan karakter dilaksanakan dengan pengembangan nilai-nilai karakter pada matakuliah Akhlak diajarkan oleh dosen kepada para mahasiswa. Karena pendidikan karakter ini sangat dibutuhkan oleh mahasiswa dalam menghadapi perubahan zaman dan degradasi moral, mahasiswa diharapkan mampu memiliki dan berperilaku dengan 
ukuran baik dan buruk yang didasarkan pada ketentuan dan ketetapan agama Islam.

Dalam “Kamus Besar Bahasa Indonesia” disebutkan bahwa akhlak adalah budi pekerti atau kelakuan. (Poerwadarwinta, 1989: 267).

Sedangkan pengertian Akhlak menurut pendapat para ahli adalah sebagai berikut :

Ibnu Maskawaih dalam Ahmad Amin (1975: 17) mendifinisikan, Akhlak adalah sikap jiwa seseorang yang mendorongnya melakukan perbuatan-perbuatan tanpa melalui pertimbangan.

Prof. Dr. Ahmad Amin (1975: 15). menjelaskan bahwa akhlak adalah kehendak yang dibiasakan.

Abu Bakar Jabir Al-jazairi (2012: 43) mendifinisikan Akhlak adalah bentuk kejiwaan yang tertanam pada diri manusia yang menimbulkan perbuatan baik dan buruk, terpuji dan tercela dengan cara yang disengaja.

Berdasarkan uraian di atas, dapat diambil kesimpulan bahwa menurut tinjauan bahasa akhlak berarti sifat, budi pekerti, perangai kebiasaan atau tingkah laku manusia. Sedangkan dari pengertian akhlak menurut tinjauan para ahli di atas, maka dapat dipahami bahwa akhlak ialah sifat-sifat yang dibawa manusia sejak lahir yang tertanam dalam jiwanya dan selalu ada padanya. Sifat itu dapat berupa perbuatan baik, yang kemudian disebut akhlak mulia, atau perbuatan buruk, yang lebih dikenal dengan sebutan akhlak tercela.

Akhlak bertjuan hendak menciptakan manusia menjadi makhluk yang tinggi dan sempurna, dan membedakan dengan mkhluk lainnya. 
Allah hendak menjadikan manusia sebagai makhluk yang baik terhadap dirinya, berbuat baik terhadap sessamanya, dan berbuat baik terhadap makhluk lain serta berbuat baik terhadap Allah SWT. Sedangkan pelajaran Akhlak bertujuan untuk mengetahui perbedaan perangai manusia yang baik dan yang buruk sehingga manusia bisa memegang perangai-perangai yang baik sehingga dapat menjauhkan diri dari praengai yang buruk sehngga tercipta tata tertib pergaulan masyarakat dimana tidak ada benci- membenci, pertengkaran, perkelahian dsengan sesamanya dimuka bumi ini.

Jadi pada hakikatnya khuluk (budi pekerti) atau akhlak ialah suatu kondisi atau sifat yang telah meresap dalam jiwa dan telah menjadi kepribadian sehingga dari situ timbullah beberapa macam perbuatan dengan cara spontan dan mudah tanpa dibuat-buat dan tanpa memerlukan pemikiran. Apabila dari kondisi tadi timbul kelakuan yang baik dan terpuji menurut pandangan syari'at dan akal pikiran, maka ini dinamakan budi pekerti yang mulia dan sebaliknya yang lahir dari kelakuan yang buruk, maka di sebutlah budi pekerti yang tercela.

Dalam matakuliah akhlak memuat materi tentang sikap dan perilaku yang baik dan benar baik kepada Allah maupun kepada sesama manusia (hablum minallah, hablum minannas), namun realitanya mahasiswa belum bisa mengaplikasikan dalam kehidupan sehari-hari baik di kampus, di rumah mapun di masyarakat, contoh: masih adanya mahasiswa yang tidak mendengarkan dan tidak memperhatikan penjelasan dosen ketika proses pembelajaran dikelas,tidak membuat tugas yang diperintahkan dosen, mahasiswa kurang patuh menjalankan 
ibadah (shalat) ketika waktu sholat tiba dan sebagainya.Bahkan Mahasiswa bersikap kurang sopan, tidak punya tatakrama terhadap dosen, kurang bisa menghargai orang lain. Dosen sudah banyak memberikan anjuran atau nasehat dalam perkuliahan namun pada umumnya mahasiswa kurang respek untuk menjalankan dengan penuh kesadaran. Bahkan mahasiswa tidak memperdulikan terhadap nasehat dan teguran doesen.

Adapaun pendidikan karakter yang diharapkan dari pembelajaran Akhlak adalah untuk membentuk identitas diri menuju kematangan pribadi. Penanaman akhlak diutamakan agar mahasiswa didik tidak mengalami kegoncangan pikiran dan jiwanya dalam menentukan solusi atau problem yang dihadapinya. Sehingga pendidikan yang pertama dan utama adalah pembentukan keyakinan kepada Allah SWT yang diharapkan dapat melandasi sikap, tingkah laku dan kepribadian mahasiswa. Dalam pemahaman pendidikan akhlak ini, mahasiswa diharapkan dapat menumbuhkan dan meningkatkan keimanannya yang diwujudkan dalam tingkah laku terpuji, membelajarkan mahasiswa untuk melakukan perbuatan baik bagi diri sendiri maupun bagi orang lain, mahasiswa juga diarahkan untuk mencapai keseimbangan antara kemajuan lahiriyah maupun batiniyah, keselarasan hubungan sesama manusia maupun lingkungannya juga hubungan vertikal dengan Tuhannya. Dengan begitu pembelajaran akhlak serta aplikasinya dalam kehidupan sehari-hari akan melahirkan ketenangan, kenyamanan, dan ketenteraman hidup, baik didunia yang fanak ini maupun diakhirat kelak yang kekal abadi. Pendidikan Akhlak adalah penanaman perilaku yang 
baik di dalam jiwa anak dalam masa pertumbuhannya, sehingga perilaku tersebut menjadi salah satu kemampuan jiwa. Selain alasan tersebut akhlak atau perilaku yang baik merupakan misi yang dibawa nabi Muhammad SAW diutus kedunia.

Pendidikan karakter dilakukan dalam rangka mencapai tujuan pendidikan nasional yaitu untuk berkembangnya potensi peserta didik agar menjadi manusia yang beriman dan bertakwa kepada Tuhan Yang Maha Esa, berakhlak mulia, sehat, berilmu, cakap, kreatif, mandiri, dan menjadi warga negara yang demokratis serta bertanggung jawab. Sedangkan menurut Muslih, (2007: 7) tujuan pendidikan karakter adalah sebagai berikut: 1). Mengembangkan potensi afektif peserta didik sebagai manusia dan warganegara yang memiliki nilai-nilai budaya dan karakter bangsa; 2). Mengembangkan kebiasaan dan perilaku peserta didik yang terpuji dan sejalan dengan nilai-nilai universal dan tradisi budaya bangsa yang religius; 3). Menanamkan jiwa kepemimpinan dan tanggungjawab peserta didik sebagai generasi penerus bangsa; 4). Mengembangkan kemampuan peserta didik menjadi manusia yang mandiri, kreatif, berwawasan kebangsaan; 5). Mengembangkan lingkungan kehidupan sekolah sebagai lingkungan belajar yang aman, jujur, penuh kreativitas dan persahabatan, serta dengan rasa kebangsaan yang tinggi dan penuh kekuatan.

Sedangkan fungsi pendidikan karakter adalah: 1). Pembentukan dan Pengembangan Potensi, pendidikan karakter berfungsi membentuk dan mengembangkan potensi manusia atau warga negara Indonesia agar berpikiran baik, berhati baik, dan berperilaku baik sesuai dengan 
falsafah hidup Pancasila; 2). Perbaikan dan Penguatan, pendidikan karakter berfungsi memperbaiki karakter manusia dan warga negara Indonesia yang bersifat negatif dan memperkuat peran keluarga, satuan pendidikan, masyarakat, dan pemerintah untuk ikut berpartisipasi dan bertanggung jawab dalam pengembangan potensi manusia atau warga negara menuju bangsa yang berkarakter, maju, mandiri, dan sejahtera; 3). Penyaring, lebih dari itu pendidikan karakter bangsa berfungsi memilah nilai-nilai budaya bangsa sendiri dan menyaring nilai-nilai budaya bangsa lain yang positif untuk menjadi karakter manusia dan warga negara Indonesia agar menjadi bangsa yang bermartabat.

Selain itu mahasiswa PGMI adalah calon guru PAI di SD atau Madrasah Ibtidaiyah yang diharapkan memiliki karakter yang menjadi figur (contoh teladan) peserta didik dalam bersikap dan bertingkah laku. Dimana sikap dan tingkah laku tersebut adalah akhlak Islam dengan ukuran baik dan benar yang sumbernya AlQur'an dan Sunnah.Hal ini sebagaimana yang dikemukakan oleh Usman (1997: 15) dalam bukunya profesionalisme guru bahwa syarat menjadi guru profesional harus memiliki syarat formal (ijazah keguruan) dan kepribadian (karakter sabar, jujur,demokratis,adil,bijaksana dan sebagainya).

Berdasarkan latar belakang tersebut di atas maka peneliti tertarik untuk mengadakan penelitian yang berjudul Pelaksanaan Pendidikan Karakter dalam Pembelajaran Akhlak pada Mahasiswa PGMI STAIN Salatiga Tahun 2013, dengan rumusan masalah sebagai berikut: 1). Bagaimana pendidikan karakter mahasiswa PGMI STAIN Salatiga?, 2). Bagaimana pelaksanaan pendidikan karakter dalam pembelajaran 
Akhlak pada mahasiswa PGMI STAIN Salatiga?, dan 3). Apa yang menjadi faktor penghambat dan pendukung pelaksanaan pendidikan karakter dalam pembelajaran Akhlak pada mahasiswa PGMI STAIN Salatiga?.

\section{Metode Penelitian}

Jenis penelitian dengan berlandaskan pada masalah, maka penelitian ini termasuk jenis penelitian kualitatif yang berdasarkan studi lapangan (field research) dengan pendekatan deskriptif naturalistik. Penelitian ini bersifat kualitatif, menggunakan pendekatan deskriptif eksploratif dengan metode naturalistik karena penelitiaannya dilakukan pada kondisi yang alamiah (natural setting). Sumber datanya ialah situasi wajar, peneliti mengumpulkan data berdasarkan observasi situasi wajar, sebagaimana adanya. Peneliti adalah instrument kunci yang mengadakan pengamatan dan wawancara sendiri (Sugiyono, 2013: 1415). Bentuk penelitian ini akan mampu menangkap berbagai informasi kualitatif dengan deskriptif yang penuh nuansa, yang lebih berharga dari pada sekedar pernyataan jumlah atau frekwensi dalam bentuk angka (Sutopo, $1990: 12$ ).

Permasalahan yang akan diungkap dalam penelitian ini adalah pendidkan karakter mahasiswa PGMI maka yang menjadi key informan dalam penelitian ini adalah mahasiswa PGMI dan dosen yang mengampu matakuliah Akhlak dipilih sebagai key informan karena mereka yang lebih paham tentang kondisi mahasiswa PGMI.

Subyek yang dimaksud dalam penelitian ini adalah mahasiswa PGMI STAIN Salatiga semester V. Adapun alasan peneliti mengambil 
subyek penelitian tersebut karena mahasiswa PGMI adalah mahasiswa yang setelah lulus akan menjadi calon guru MI atau guru Pendidikan Agama Islam SD diharapkan memiliki karakter yang baik.

Penelitian ini menggunakan metode interaktif dan metode non interaktif (Sugiyono, 2013: 27). Metode interaktif meliputi observasi berperan dan wawancara, sedangkan metode non interaktif meliputi observasi dan analisis dalam dokumen.

Sesuai dengan bentuk pendekatan penelitian kualitatif dan sumber data yang akan digunakan, maka teknik pengumpulan data yang digunakan dalam penelitian ini adalah sebagai berikut: 1). Metode wawancara ini bertujuan memperoleh data atau informasi dari responden (key informan) tentang pendidikan karakter mahasiswa dalam pembelajaran Akhlak yakni, dosen PGMI STAIN Salatiga. Key informan itulah yang memahami kompleksitas persoalan mahasiswa di kampus tersebut.

Riset ini juga akan menggunakan teknik Focus Group Discussion (FGD) untuk kebutuhan melengkapi data tentang kondisi mahasiswa. Secara umum teknik ini akan mengambil sampel dari mahasiswa. Penggalian data melalui diskusi kelompok ini dimaksudkan agar peneliti dapat menghimpun data dari hasil sharing pengalaman informan.

Metode observasi dilakukan dengan pengamatan langsung dan pengamatan tidak langsung terhadap obyek yang diteliti (Arikunto, 1993: 1). Pengamatan langsung ini dilakukan oleh peneliti untuk memperoleh data yang berhubungan dengan gambaran riil dan detil mahasiswa PGMI, begitu juga tentang keadaan dosen dalam pembelajaran dikelas. 
Sedangkan pengamatan tidak langsung dilakukan untuk memperoleh data tentang persepsi dosen terhadap pendidikan karakter mahasiswa di kampus.

Metode dokumentasi digunakan untuk mencari data mengenai halhal yang berupa catatan, tulisan, arsip atau dokumen (Nazir, 1999: 56). Catatan dan tulisan tersebut berupa UU Sisdiknas, peraturan pemerintah, jurnal, dan catatan penilaian dosen . Dokumen tersebut dapat dijadikan data pendukung dalam penelitian ini.

Teknik analisis data dalam penelitian ini adalah deskriptifeksploratif-analisis. Dimana analisis data merupakan upaya mencari dan menata secara sistematis catatan hasil observasi, wawancara, dan lainya untuk meningkatkan pemahaman peneliti tentang fenomena yang diteliti dan menyajikannya sebagai temuan bagi orang lain (Muhadjir, 1996: 171).

Analisa data sebagaimana menurut Patton yang dikutip oleh Lexy $\mathbf{J}$ Moleong adalah proses mengatur urutan data, mengorganisasikannya kedalam suatu pola, kategori, dan satuan uraian dasar (Moleong, 2010: 103).

Analisis dilakukan atas data yang ditemukan di lapangan, dan bukan sebagai upaya untuk menguji teori yang telah ditetapkan sebelumnya, mengingat bahwa penelitian kualitatif menolak pra-konsep sebelum terjun di lapangan (Muhajir, 1996: 166).

Adapun metode analisis data (primer maupun sekunder) yang digunakan dalam penelitian ini adalah metode induktif dan deduktif, yang pada prinsipnya merupakan cara berfikir untuk mencari dan 
menguasai ilmu pengetahuan yang berasal dari alasan umum ke arah yang lebih spesifik. Logika deduktif merupakan sistem berfikir untuk mengorganisasi faktual dan mencapai suatu kesimpulan dengan menggunakan argumentasi logika (yang dapat diterima oleh akal), sedangkan logika induktif adalah kebalikan dari logika deduktif (Sudjana, 2001: 12).

Adapun langkah-langkah analisis data dalam penelitian ini menurut Miles dan Huberman dalam Sugiyono (2010: 246) adalah sebagai berikut: 1). Menelaah data yang berhasil dikumpulkan dari hasil observasi, wawancara dan dokumentasi; 2). Mengadakan reduksi data dengan cara mengambil data yang dapat diolah lebih lanjut; 3). Menyusun data dalam satuan-satuan yang relevan; 4). Melakukan kategorisasi sambil melakukan pengkodean (coding); 5). Mengadakan pemeriksaan keabsahan data; 6). Menafsirkan data dan mengambil kesimpulan secara induktif dengan cara berfikir berdasarkan fakta-fakta khusus, kemudian diarahkan kepada penarikan kesimpulan yang bersifat umum.

\section{Pembahasan}

\section{Pendidikan Karakter Mahasiswa PGMI}

Berdasarkan hasil wawancara dengan salah satu dosen pengampu matakuliah Akhlak di PGMI pada hari Rabu tanggal 14 Nopember 2013 dapat dipahami bahwa mayoritas mahasiswa PGMI memiliki karakter yang baik. 
Hal ini dapat dibuktikan berdasarkan hasil pengamatan karakter mahasiswa PGMI pada hari Senin tanggal 17 Nopember 2013 yang hasilnya dari 15 karakter yang diamati religius, jujur, toleransi, disiplin, kerja keras, kreatif, mandiri, demokratis, rasa ingin tahu, semangat kebangsaan, bersahabat, cinta damai, peduli lingkungan, peduli sosial, dan tanggung jawab hanya ada 2 karakter yang masih kurang yaitu rasa ingin tahu dan peduli lingkungan. Sebagaimana deskripsi berikut:

Bagaimana karakter mahasiswa PGMI?. Jawabannya: "Mayoritas karakter mahasiswa PGMI baik karena perilaku sehari-hari dalam pembelajaran cukup baik, karena dari awal masuk sudah ada niat masuk PGMI itu nantinya menjadi calon guru ,jadi mereka sudah memiliki karakter keguruan".

Bagaimana cara bapak mengetahui karakter mahasiswa dalam pembelajaran Akhlak?. Jawabannya:"Melalui pengamatan dalam proses pembelajaran ,ketika mahasiswa berinteraksi dengan temannya,ketika mahasiswa presentasi di depan kelas dalam menyampaikan tugas, ketika mahasiswa komunikasi dengan dosen, dan ketika diskusi dikelas".

Berdasarkan hasil observasi atau pengamatan juga dengan salah satu mahasiswa PGMI yang berinisial D pada hari senin tanggal 17 Nopember 2013 diperoleh data sebagai berikut: Dari 15 karakter ( religius, jujur, toleransi, disiplin, kerja keras, kreatif, mandiri, demokratis, rasa ingin tahu, semangat kebangsaan, bersahabat, cinta damai, peduli limgkungan, peduli sosial, dan tanggung jawab)mahasiswa PGMI tersebut yang peneliti amati hampir 
Mudarrisa: Jurnal Kajian Pendidikan Islam, Vol. 5, No.2, Desember 2013: 169-194

semuanya nilainya baik, hanya karakter rasa ingin tahu dan peduli lingkungan yang masih kurang.

Dari 15 karakter tersebut dapat peneliti deskripsikan sebagai berikut: 1). Perilaku religius, dengan indikator taat menjalan kan sholat fardlu, dapat peneliti diskripsikan dalam perilaku sebagai berikut: "Pembelajaran akhlak telah selesai jam menunjukkkan pukul 11.50 mahasiswa pada keluar kelas dan suara adzan sudah berkumandang, mereka langsung bergegas menuju mushola untuk menjalankan sholat dhuhur". Maka dapat dipahami bahwa anak memliki perilaku religius yaitu taat menjalankan sholat fardlu; 2). Perilaku jujur, dengan indikator berusaha mengerjakan tes sendiri/tidak nyontek dapat peneliti deskripsikan dalam perilaku sebagai berikut: "ujian tengah semester berlangsung dengan tenang para mahasiswa mengerjakan dengan serius dan teliti sampai waktunya habis tapi ada mahasiswa tersebut yang masih duduk dan mengerjakan soal dan itu sampai waktunya habis belum selesai ternyata masih ada beberapa soal yang belum diisi dan ketika ditanya oleh salah satu penjaga tes" kenapa ada beberapa soal yang tidak dikerjakan mba ? jawabnya : karena tidak bisa jawab bu"; 3). Perilaku toleransi, dengan indikator tidak mengganggu teman yang sedang fokus belajar dapat peneliti deskripsikan sebagai berikut: "Diskusi kelompok dalam pembelajarn akhlak sedang berlangsung ketika itu ada salah satu mahasiswa yang tugasnya ketinggalan dirumah yang tidak jauh dari kampus karena temannya sedang asik diskusi ia tidak mau mengganggu, maka langsung saja bergegas ia pamit pada dosen untuk pulang sendirian mengambil tugas di rumah”; 4). Perilaku Disiplin, dengan indikator masuk kelas tepat waktu dapat peneliti deskripsikan sebagai berikut: "jadwal kuliah Akhlak adalah jam 3,4 atau jam 08.40 peneliti datang ke kelas tapi dosen pengampu belum datang, malah didalam kelas sudah ada beberapa mahasiswa menunggu, ketika peneliti tanya kepada salah satu mahasiswa tersebut jawabnya sudah ada atau belum ada dosen saya tetap kuliah karena waktunya kuliah saya tetap masuk dan menunggu dosen datang”; 5). Kerja keras,dengan indikator berusaha mengerjakan tugas dosen dengan sebaik-baiknya dapat peneliti deskripsikan sebagai berikut. Setiap akhir semester dosen memberikan tugas individu dengan waktu satu minggu sebelum UAS atau pertemuan terakhir harus sudah dikumpulkan tapi ada mahasiswa yang belum mengumpulkan ketika ditanya oleh dosen mana tugas anda? 
Jawab mahasiswa:" saya belum mengumpulkan tugas pak". Jawab dosen:"Kenapa belum mengumpulkan?. jawab mahasiswa:" belum jadi pak karena buku referensi yang sesuai dengan tema belum ketemu padahal saya sudah berusaha mencari kemana-mana mencari diperpustakaan , saya ingin hasilnya baik”; 6). Perilaku Kreatif, dengan indikator menghasilkan karya yang menarik dapat peneliti deskripsikan sebagai berikut: "Dalam pembelajaran ada materi micro teaching dimana masing-masing mahasiswa maju satu persatu praktik pembelajaran pada waktu itu itu ada salah satu mahasiswa yang menggunakan media pembelajaran yang bagus berupa tas bagus sekali kemudian peneliti dekati dan amati ternyata alat peraga tadi terbuat dari bahan bekas bungkus minuman kemasan plastik"; 7). Perilaku Mandiri, dengan indikator mengerjakan tugas sendiri tanpa meminta bantuan orang lain atau disuruh dapat peneliti deskripsikan sebagai berikut : "Setiap dosen dalam perkuliahan memberikan tugas baik bersifat individu atau kelompok, biasanya mahasiswa membuat makalah kemudian didiskusikan, pada waktu itu kebetulan dosen tidak hadir karaena adala acara lain, namun diskusi tetap jalan sampai selesai tanpa ditunggu atau didampingi dosen tersebut”; 8). Perilaku demokratis, dengan indikator menyelesaiakan masalah di kelas didiskusikan bersama temannya dapat peneliti deskripsikan sebagai berikut: "Peneliti melihat mahasiswa pada rame dan ribut terus kemudian peneliti menaya kepada salah sat mahasiswa: "ada apa kok pada rame-rame mbak?. Mahasiswa tersebut menjawab: ini lo bu kuliah kosong sudah tiga kali. Peneliti bertanya: dimana ketua kelanya?. Mahasiswa tersebut menjawab: Baru berembug dengan teman-teman lain bagaimana kalau masalah ini disampaikan kepada prodi PAI". Peneliti menjawab: ya sudah kalau sudah disampaiakan pada prodinya"; 9). Perilaku rasa ingin tahu, dengan indikator sering bertanya tentang materi pelajaran dapat peneliti deskripsikan sebagai berikut: "Dalam pertemuan perdana atau awal kuliah masuk dosen memberikan silabus yang isinya topik materi yang akan disampaikan selama satu semester, saat itu dosen memberikan tugas untuk membuat makalah secara berkelompok pada waktu dosen membagi kelompok dan pembagian tema materi yang diberikan. Namun ketika sampai pada waktunya presentasi mahasiswa belum siap dan dosen kecewa. Saat itu peneliti amati dosen dengan muka sedih dan kecewa. Setelah dosen keluar dari ruangan peneliti tanya: pak kenapa tadi bapak kelihatan 
Mudarrisa: Jurnal Kajian Pendidikan Islam, Vol. 5, No.2, Desember 2013: 169-194

sedih? Jawab beliau: karena mahasiswa belumbuat makalah untuk presentasi dengan alasan tidak punya bukunya; 10). Perilaku semangat kebangsaan, dengan indikator mengikuti kegiatan yang berhubungan dengan semangat persatuan dapat peneliti deskripsikan sebagai berikut: Pada hari jum'at jam 15.00 di depan aula kampus I peneliti melihat mahasiswa berseragam pramuka lengkap berkumpul dan berbaris.Peneliti langsung mendekati responden tersebut dan bertanya ada acara apa mba berkumpul disini dan berseragam pramuka? Jawab responden:latihan /gladi bersih untuk upacara hari jadi pramuka bu"; 11). Perilaku Bersahabat, dengan indikator ramah terhadap teman dapat peneliti deskripsikan sebagai berikut: "Kuliah jam ke tiga (08.40 10.20) sudah masuk namun baru ada beberapa mahasiswa yang datang kebetulan juga dosennya belum hadir sebentar kemudian jeda 5 menit pak dosen masuk diikuti mahasiswanya, ketika itu mahasiswa pada berjabat tangan dengan dosen dan mengucapkan salam (Assalamu'alaikum pak dengan senyum) "; 12). Perilaku cinta damai, dengan indikator rukun sesama teman dapat peneliti deskripsikan sebagai berikut: "Kuliah Akhlak masuk jam 10.20 (jam ke-3) namun dosen belaum datang padahal mahasiswa sudah separo lebih yang hadir, keadaan kelas tetap tenang karena dosen sudah menyampaikan pesan kalau datang terlambat, mahasiswa kerjasama mengerjakan tugas bersama-sama (membuat makalah) keadaan ini berlangsung sampai dosen masuk kelas) dan bertanya tugasnya sudah selesai, sudah pak"; 13). Perilaku Peduli lingkungan, dengan indikator tidak membuang sampah disembarang tempat dapat peneliti deskripsikan sebagaia berikut: "Kuliah akhlak yang biasanya masuk jam 10.20 (jam ke-3) diganti jam 14.20 karena dosen ada acara dinas luar, saat itu dosen masuk kelas agak awal, ketika masuk dosen terkejut melihat ruangan kelas lantainya kotor banyak bungkus permen dan kertas "; 14). Peduli sosial, dengan indikator suka menolong temannya dapat penulis deskripsikan sebagai berikut: "Pada waktu kuliah sedang fokus dan baru berjalan setengah jam adaseorang mahasiswi yang tiba-tiba pingsan langsung saja temantemannya pada terkejut, waktu itu seorang mahasiswi mendekati dosennya kemudian berkata: "pak saya mohon ijin untuk mengantarkan teman tadi yang pingsan ke poliklinik ya kasihan kalau nanti ada apaapa, Dosen tersebut menjawab: "dengan teman lain untuk menemani , tidak usah cukup saya saja biar kuliahnya tetap jalan". Jawab dosen:"Ya sudah terimakasih"; 15). Tanggung jawab,dengan indikator 
meneyelesaikan tugas dan kewajibannya sendiri dapat peneliti deskripsikan sebagai berikut: "Setiap dosen dalam perkuliahan memberikan tugas baik individu maupun kelompok, pada waktu itu ada seorang mahasiswi yang belum mengumpulkan tugas padahal waktunya tinggal satu hari,dikarenakan ia banyak kegiatan ekstra kampus yaitu pramuka dan senat, meskipun demikian ia tetap semangat berusaha mengerjakan tugas sampe tidak tidur dan sempat bilang pada dosen kalau minta waktu satu hari saja menyelesaikan tugas tersebut dan akhirnya ndosen mengijinkannya".

Hal ini sebagaimana pendapat Usman (1999: 27) bahwa syarat menjadi calon guru harus memenuhi syarat formal dan syarat kepribadian. Syarat formal adalah memiliki ijazah keguruan. Sedangkan syarat kepribadian adalah memiliki karakter dan perilaku sabar, ramah, tanggung jawab, disiplin, mandiri, jujur, demokratis, adil, berwibawa, fleksibel, kreatif, pemaaf, dan sebagainya. Semuanya itu mencerminkan seorang guru yang memiliki pribadi yang luhur dan mulia yang nantinya menjadi contoh bagi peserta didiknya.

Selain itu mahasiswa PGMI sudah memiliki niat atau tujuan menjadi calon guru maka mereka sudah mempersiapkan diri menata diri baik secara fisik maupun psikologi untuk berbicara, bersikap maupun berperilaku yang mencerminkan sosok seorang guru. Hal ini sebagaimana hasil wawancara peneliti dengan salah satu responden yang berinisial AS yang mengatakan bahwa: "Mahasiswa PGMI memang pada umumnya dari awal sudah kelihatan memiliki karakter keguruan, sehingga mereka mudah untuk dibimbing dan diarahkan serta mudah untuk dikondisikan dalam sikap,dan perilaku yang baik atau "gampang diatur”, contohnya kuliah rajin, disiplin, kalau 20 menit dosennya belum masuk ya langsung di sms atau ditelpon”. 
Hal ini dapat dibuktikan dalam hasil pengamatan atau observasi perilaku disiplin salah satu mahasiswa yang berinisial D sebagai berikut : "mahasiswa sudah pada duduk di kelas menuggu dosen jumlahnya sekitar 20 orang, waktu itu peneliti menanyakan pada mahasiswa yang peneliti amati tersebut sebagai berikut:

$P \quad$ : sedang apa mba duduk di dalam kelas ini ?"

D : Menunggu dosen bu masuk kelas".

$P \quad$ : Jam kuliah kan masih 5 menit lagi?

D : Tidak apa-apa bu dari pada terlambat masuk kuliah”.

\section{Pelaksanaan Pendidikan Karakter mahasiswa PGMI}

Pelaksanaan pendidikan karakter dalam pembelajaran Akhlak mahasiswa PGMI menggunakan strategi atau metode keteladanan atau pemberian contoh perilaku yang baik kepada mahasiswa, pembiasaan, perumpamaan (amtsal), dan metode nasehat, Hal ini sebagaimana pendapat Masnur Muslih bahwa penerapan pendidikan karakter dailakukan dengan strategi pengintegrasian dalam kegiatan sehari-hari.

Hal ini sebagaimana wawancara peneliti dengan salah satu dosen Akhlak tentang strategi penggunaan keteladanan, pembiasaan, perumpamaan, dan nasehat dalam pembelajaran Akhlak adalah sebagai berikut :

\section{Penggunaan strategi keteladanan}

P : Bagaimana cara bapak menerapkan metode keteladanan dalam pendidikan karakter mahasisiwa? 
AS : Saya memulai mengajak bersalaman atau berjabat tangan dengan mahasiswa, dengan demikian mahasiswa akan menirukan".

\section{Penggunaan strategi pembiasaan}

$\mathrm{P} \quad$ : “ bagaimana cara bapak menerapkan metode pembiasaan dalam pendidikan karakter mahasiswa?

AS : "Saya menyapa lebih dulu ketika bertemu dengan mahasiswa, bukan mahasiswa yang harus menyapa sya (dosen), dengan demikian mahasiswa akan memiliki sikap atau karakter ramah kepada siapapun”.

\section{Penggunaan strategi perumpamaan}

$\mathrm{P} \quad$ : "bagaimana cara bapak menerapkan startegi perumpamaan dalam pendidikan karakter mahasiswa ?"

AS : "Mengisahkan atau menceritakan hasil pengalaman langsung atau tidak langsung para tokoh Islam seperti karakter sabar yang dalam cerita nabi Muhamad menyuapi pengemis yahudi yang buta setiap pagi dengan harapan nabi agar pengemis tersebut mau masuk Islam".

P : Apa hikmah dari cerita tersebut Pak?"

AS : Agar mahasiswa bisa mengambil intisari dari kisah tersebut".

\section{Penggunaan strategi nasehat}

P : Bagaimana cara bapak menerapkan strategi nasehat dalam pendidikan karakter mahasiswa?" 
AS : Dengan memberi nasehat ketika melihat mahasiswa berbuat tidak benar, berteriak di dalam kelas misalnya".

Dari dialog di atas, secara global dapat dijelaskan bahwa dalam penggunaan strategi atau metode yang digunakan bapak/ibu dosen dalam pelaksanaan pendidikan karakter dalam pembelajaran Akhlak adalah: Dengan memberikan contoh tauladan pada mahasiswa baik tentang perkataan sikap maupun perilaku, contohnya bertutur kata yang baik dan sopan kepada mahasiswa, bersikap ramah terhadap mahasiswa, sabar dalam menghadapi mahasiswa yang terlambat masuk dan sebagainya.

Menggunakan perumpamaan dengan cerita kisah perilaku para rasul, dan sahabatnya, contohnya Muhamad itu rasul yang sabar, pemaaf, dan dermawan terhadap siapapun, bahkan kepada pengemis yahudi yang buta setiap pagi dan sore selalu disuapi meskipun dia marah-marah dalam membalas perlakuan kepada Rasulullah Muhamad yang baik tersebut".

Nasehat atau bimbingan, sebagai contohnya bersikap hormat kepada dosen dan mahasiswa bahkan orang lain.

Perumpamaan, sebagai contoh kisah pengalaman diri sendiri atau para tokoh Islam, Nabi Muhamad misalnya.

Teguran atau peringatan secara tidak langsung, contohnya teguran itu dilakukan ketika mahasiswa melakukan kesalahan dan itupun secara tidak langsung terhadap tingkah laku mahasiswa tapi melalui pengalaman dan kaitkan dalam materi pembelajaran.

Dalam meningkatkan perilaku yang baik kepada mahasiswa bapak/ibu dosen melakukan beberapa hal, antara lain: Menjaga 
lingkungan pembelajaran yang kondusif, Menjadikan diri pribadi yang bisa diteladani mahasiswa (orang lain), dan Memaksimalkan penggunaan metode, media dan fasilitas lain dalam pembelajaran.

Sedangkan dalam mengontrol perilaku mahasiswa dalam pembelajaran Akhlak mahasiswa PGMI bapak/ibu dosen membuat kontrak pembelajaran yang berisi tentang tata tertib atau peraturan yang disepakati dalam proses pembelajaran.

\section{Faktor yang Menghambat dan Mendukung pelaksanaan pendidikan} Karakter

Berdasarkan hasil penelitian dapat diketahui bahwa faktor yang menjadi penghambat dan pendukung pelaksanaan pendidikan karakter dalam pembelajaran Akhlak mahasiswa PGMI adalah sebagai berikut :

\section{Faktor penghambat}

Faktor penghambat yaitu faktor dari individu mahasiswa yang meliputi pembawaan dan keluarga. Hal ini sebagaimana hasil wawancara peneliti dengan responden pada tanggal 14 Nopember 2013 yang hasilnya dapat penulis tarik benang merah bahwa Mayoritas mahasiswa PGMI berasal dari pedesaan dan lingkungan keluarga Islam, mereka masih lugu atau polos, ya ada sebagian kecil yang berasal dari lingkungan perkotaan dari keluarga awam (umum".)

\section{Faktor pendukung}

Faktor yang menjadi pendukung dalam pelaksanaan pendidikan karakter dalam pembelajaran akhlak mahasiswa PGMI yaitu faktor yang berasal dari lingkungan kampus dan masyarakat. Hal ini sebagaimana 
hasil wawancara peneliti dengan responden pada tanggal 14 Nopember yang dapat penulis tarik benang merah bahwa kondisi kampus 2 sebagai tempat kuliah mahasiswa PGMI yang jauh dari perkotaan atau pinggiran kota dan belum terkena polusi pergaulan bebas maka mereka masih mudah untuk dibimbing dan diarahkan, lebih dari itu mahasiswa STAIN semuanya umat Islam sehingga untuk menanamkan nilai karakter kepada siswa lebih mudah dan cepat terarah. Dan dari hasil pengamatan peneliti terhadap perilaku mahasiswa yang peduli sosial yaitu mau menolong teman yang sedang sakit.

Sedangkan Faktor ekstern dari fasilitas pembelajaran seperti metode, media pembelajaran yang dapat menjadi pendukung pendidikan karakter dalam pembelajaran akhlak mahasiswa PGMI sebagaimana hasil wawancara peneliti dengan responden pada tanggal 14 Nopember 2013 yang mangatakan bahwa: "sudah terpenuhinya media atau sumber belajar yang digunakan oleh dosen maka hasil pembelajaran dapat maksimal, hanya saja penggunaan media berbasis ICT oleh mahasiswa yang tidak dapat dipantau oleh dosen atau orang tua yang menjadi penghambat dalam pembentukan karakter".

Hal ini dapat dibuktikan peneliti dalam hasil pengamatan perilaku mahasiswa yang mengakses internet tidak mencari pengetahuan kaitannya dengan materi kuliah yang disampaikan dosen tapi malah sebaliknya mencari pengetahuan lain yang tidak sesuai dengan materi kuliah. 


\section{Kesimpulan}

Pendidikan karakter mahasiswa PGMI pada umumnya sudah baik. Dari 15 karakter yaitu religius, jujur, toleransi, disiplin, kerja keras, kreatif, mandiri, demokratis, rasa ingin tahu, semangat kebangsaan, bersahabat, cinta damai, peduli limgkungan, peduli sosial, dan tanggung jawab, hanya karakter rasa ingin tahu dan peduli lingkungan yang masih kurang.

Pelaksanaan pendidikan karakter mahasiswa PGMI STAIN Salatiga dalam pembelajaran Akhlak adalah dengan strategi pemberian contoh keteladanan, pembiasaan, perumpamaan, dan nasehat.Selain Strategi itu dilakukan juga pengamatan perilaku mahasiswa dalam interaksi pembelajaran.

Faktor yang menjadi penghambat pelaksanaan pendidikan karakter dalam pembelajaran akhlak mahasiswa PGMI adalah sifat bawaan masing-masing mahasiswa (individu) dan lingkungan keluarga yaitu latar belakang karakter anak dalam keluarga. Sedangkan faktor pendukung pelaksanaan pendidikan karakter dalam pembelajaran akhlak mahasiswa PGMI adalah lingkungan kampus seperti pergaulan mahasiswa dan penggunaan media berbasis teknologi (internet) serta metode dan media pembelajaran dosen menjadi faktor pendukung yang paling dominan terhadap pelaksanaan pendidikan karakter mahasiswa.

\section{Daftar Pustaka}

Amin. Ahmad, 1975. Etika Ilmu Akhlak. Jakarta: Bulan Bintang. Al-Jazairi, Abu Bakar Jabir. 2012. Minhajul Muslim (Pedoman Hidup Ideal Seorang Muslim). Yogyakarta: Insan Kamil. 
Bogdan dan Biklen. 1982. Qualitative Research for Education: An Introduction to Theory and Methods. Boston : Allyn and Bacon Inc.

Ilyas Yunahar. 2007. Kuliah Akhlak. Yogyakarta: Pustaka Pelajar Offset. Miftachurrif'ah. 2012. Pendidikan Karakter di MI kota Salatiga. P3M STAIN Salatiga.

Miles Huberman. 1992. Analisis Data Kualitatif: Buku Sumber Tentang Metode-Metode Baru. Terj. Tjejep Rohendi. Jakarta: UI Press.

Muhajir, Noeng. 1996. Metode Penelitian Kualitatif. Yogyakarta: Rake Sarasin.

Moleong, Lexy J. 2010. Metode Penelitian Kualitatif. Bandung: Remaja Rosda Karya.

Muslih Masnur. 2011. Pendidikan Karakter: Menjawab Tantangan Krisis Multidimensial. Jakarta: Bumi Aksara.

Nazir Moh. 1999. Metode Penelitian. Jakarta: Galia.

Poerwadarwinta. WJS. 1989. Kamus Besar Bahasa Indonesia. Jakarta: Balai Pustaka.

Samsuri. 2011. Pendidikan Karakter Warga Negara, Yogyakarta: Diandra Pustaka Indonesia.

Sudjana, Nana. 2001. Prosedur Penelitian Kualitatif. Bandung: Remaja Rosdakarya.

Sugiyono, 2013, Metode Penelitian Pendidikan, Pendekatan Kuantitatif, Kualitatif, dan $R \& D$, Bandung: Alfabeta

Arikunto. Suharsimi, 2002. Prosedur Penelitian Suatu Pendekatan Praktis. Jakarta: Rineka Cipta.

Sutopo. 1990. Metodologi Penelitian Qualitatif I : Dasar Teoritis dan Karakteristiknya. Surakarta: UNS.

Usman Uzzer. 1995. Upaya Peningkatan Profesionalisme Guru. Bandung: Rineka Cipta.

http://Kompas.com, diakses tanggal 21 Mei 2011

http://Pendikar.unnes.ac.id diakses tanggal 24 Nopember 2013 